\title{
THE IMPACT OF THE ROMANIAN EU COUNCIL PRESIDENCY ON THE DEGREE OF INCLUSIVENESS OF NON-GOVERNMENTAL ACTORS IN THE NATIONAL SYSTEM FOR COORDINATION OF EUROPEAN AFFAIRS
}

\author{
Alexandra Loy, PhD \\ Department of International Relations and European Integration \\ National University of Political Studies and Public Administration (SNSPA) \\ Bucharest, Romania \\ alexandra.loy@student.dri.snspa.ro
}

\begin{abstract}
The efficient and professional exercise of the first Romanian EU Council Presidency is possible upon a thorough preparation that adds pressure on the national system for coordination of European affairs to adapt its administrative and coordination capacity not only with regard to logistical aspects of the Presidency's activities, but also to the elaboration of the political programme implemented during the six month mandate. Hence, concerted action involving both the central public administration and non-governmental actors is necessary to maximize all the expertise available on EU issues in order to build a strong European outlook for the Presidency role. The paper assesses the Council Presidency's potential to affect the development of the coordination system in the long run related to its nature in terms of the degree of inclusiveness of nongovernmental actors in the process of defining the national position on European affairs. In this sense, an analysis of the framework for cooperation between the government and the civil society representatives in general and in the context of the preparations for the Presidency was conducted through the theoretical lens of the critical junctures concept in order to establish whether the transformations
\end{abstract}


triggered by this event might have reorganized the pre-existent institutional arrangements of the system. The analysis has revealed that although the involvement of civil society actors in European affairs has increased in the last 2 years, a close cooperation with the Government is unlikely to continue in the future past the Presidency, meaning that the latter fails to be a critical juncture in the development of the coordination system.

\section{Keywords}

Civil society, coordination system, Council Presidency, critical juncture, European affairs, Romania

\section{INTRODUCTION}

The current research ${ }^{1}$ is placed in the context of the preparatory process for the Presidency of the Council of the European Union that will be taken over for the first time by Romania on January $1^{\text {st }} 2019$. The exercise of the Presidency is not only an opportunity for Romania to be at the centre of decision-making at the European level and contribute to the best of its ability to the evolution of the European project and its policies, thus enhancing its image, but it is also an obligation to ensure the smooth functioning of the Council's activity in terms of coherence and continuity of the legislative work, act as an honest broker and consensus facilitator in the negotiations on thematic dossiers and last but not least, be a reliable partner in relation to the other member states and EU institutions in order to advance the objectives on the European agenda. In this sense, the exercise of the Presidency will be a challenge for Romania as it will be

1 The current paper contains extracts from the authors' Doctoral Thesis titled "The Impact of Romania's Presidency of the Council of the European Union on the National System for Coordination of European Affairs", defended during an oral presentation on September 26 2018 in Bucharest, at the headquarters of the National University for Political Studies and Public Administration. 
carried out at the end of an institutional cycle, when all pending dossiers must be closed before another Commission and heads of the European Parliament and European Council are designated, but also in the context related to the difficult negotiations on the future relationship with the United Kingdom after Brexit and the multi annual financial framework for the period 2021-2027. On the other hand, it should also be remembered that besides the supranational dimension of the Presidency, there will be one at the national level focused on hosting official delegations of the EU institutions for events, informal meetings of the Council, workshop and seminars on sectorial issues, as well as delegations of the European Parliament or the other member states' national parliaments under the parliamentary dimension of the Council Presidency. Therefore, the workload and need for better coordination within the national system for coordination of European affairs will certainly increase and solutions to effectively manage the exercise of the Presidency should be devised.

With regard to the motivation underpinning the current research, I have chosen to focus my attention on how the Presidency of the EU Council influences the national system for coordination of European affairs in the wider context of studies on the significance of the presidency of the Council after the entry into force of the Treaty of Lisbon because I found it interesting to analyse how the institutional architecture at home is modelled by the preparations for this mandate, even more when they represent a premiere for the Romanian authorities involved in the management of the European integration process. Additionally, this kind of study represents not only a novelty with reference to the elements of originality that it brings when analysing an on-going process happening for the first time in Romania, but also an important contribution to the scholarly literature that is generally under-developed and which addresses the supranational dimension of the Presidency of the EU Council, to the detriment of the domestic one.

The scholarly literature studying the Presidency of the EU Council post-Lisbon is still an under-developed research field; most of the papers focus on issues such as the significance of EU Council Presidency in the context of the Treaty of Lisbon (Udovič and Svetličič 2012; Dinan 2013, Puetter 2014, Schout 2017), the capacity to shape the agenda/the leadership and agenda-setter roles of the 
Council Presidency (Van Hecke and Bursens 2011, Verhoeff and Niemann 2011, Alexandrova and Timmermans 2012, Smeets and Vennix 2014, Karolewski et al. 2017), the continuity of the legislative work of the Council (Udovič and Svetličič 2012; Warntjen 2013; Jensen and Nedergaard 2014; Raik 2015; Van Gruisen et al. 2017), the positioning on different policies vis-à-vis other institutional actors (Vanhoonacker et al. 2011) or the conditions for influence/success of the Presidency (Vandecasteele, Bossuyt and Orbie 2013; Svetličič and Cerjak 2015; Vilpišauskas, Vandecasteele and Vaznonytè 2015). In addition to this, there are several studies that provide assessments of how the Presidency of the Council was handled by several Member States but these are generally descriptive (Karlas 2009, Bergmüller 2010; Lajh 2010, Kaczinsky 2011, Adler-Nissen et al., 2012, Kaniok and Steigrova 2014). Taking into account the literature gap regarding the domestic dimension of the Council Presidency, the current research may represent a step forward in this direction and may open new avenues of research for other researchers.

The paper is organized in six sections as follows: the introductory part, outlining the context of the study, the motivation underpinning the research and an overview of the state-of-the-art scholarly literature on the Council Presidency; the theoretical and outline of research section explaining the concept of critical junctures and its use for the current study as well as how the analysis is constructed; the methodology section detailing on the methods and approach employed for data collection; the analysis divided into two sections, the first tracing back the general framework of cooperation between the Government and the non-governmental/civil society actors to the earliest days of the national system for coordination of European affairs, while the second assessing this relation and the changes brought to it by the preparations for the EU Council Presidency; and finally, the concluding section summarizing the main findings of the study. 


\section{THEORETICAL APPROACH AND OUTLINE OF THE RESEARCH}

In order to provide more consistency, the paper will also have an important theoretical foundation as I will study the impact of the EU Council Presidency on the national system for coordination of European affairs through the concept of critical junctures stemming from historical institutionalist theory. The concept applies only to the analysis of path dependent institutions (where institutional arrangements implemented at a certain point in time become settled because of their capacity to shape the behaviours of organizational actors and outcomes in the long run) and it is a moment in which "uncertainty as to the future of an institutional arrangement fosters the ability of political agency and choice to play a decisive causal role in setting an institution on another stable path of development" (Capoccia 2015, 150). In simpler words, critical junctures are brief periods of time in which decisions made by actors can influence the development of an institution in the future.

In the context of the present research, the underlying assumption of the paper is that the Presidency of the Council of the European Union is a critical juncture in the development of the national system for coordination of European affairs in Romania. However, due to the timeframe of the analysis that ends right before the final phase of the organization process, the applicability of the critical junctures concept can only be predicted. As such, the Presidency of the Council of the European Union is perceived as a critical juncture as long as its potential to produce change is proven. In order to substantiate this claim, I employed the process-tracing approach as an instrument to rebuild the causal chain between the outcome of the critical juncture, namely the transformations in the organization and functioning of the national system for coordination of European affairs and the critical juncture itself, respectively the Presidency of the EU Council in the context of the preparatory process. Specifically, I mapped out the development of the national coordination system for European Affairs with regard to the nature of the coordination system in terms of the degree of selectivity/comprehensiveness (indicator: the number of actors participating in 
the formulation of the national position, with a focus on the civil society/nongovernmental actors). The analysis was concluded in two separate stages that are highly interconnected: in order to identify the changes to the nature of the coordination system in terms of the degree of inclusiveness/comprehensiveness in the context of the preparations for the Council Presidency, I had to first see how the system presented itself in general and as such I traced back its evolution to the formal beginning of the European integration process in 1995. Building on the findings of the first stage, I then analysed the transformations that had occurred in the relationship between the Government and the civil society representatives as a result of the preparatory process for the Council Presidency. Finally, I was able to assess the potential of this event to produce lasting change in the national system for coordination of European affairs with regard to its nature in terms of the degree of inclusiveness/comprehensiveness of other actors.

\section{METHODOLOGY}

In order to collect both primary and secondary data that was subsequently analysed and interpreted in the attempt to verify the research hypothesis that the Presidency of the Council of the EU is a critical juncture in the development of the national system for coordinating European affairs, I have employed methods popular with the qualitative research design such as:

A qualitative questionnaire designed to obtain relevant and unique information from institutional sources that otherwise would not be accessible. In this regard, I addressed 30 questionnaires to the institutions of the central public administration with a high level of expertise and responsibilities in the management of European affairs (to 24 line ministries, the Parliament of Romania, the Presidential Administration, the Permanent Representation of Romania to the EU and to the Ministry of Foreign Affairs) in order to obtain qualitative information on how the coordination is conducted in the context of the preparations for the EU Council Presidency. Only half of the ministries were able to provide focused and useful information, while the rest of them either 
referenced me to the MFA or did not reply at all. The communication with the line ministries, as well as with the other institutions mentioned above was facilitated based on the provisions of the Law no. 544/2001 regarding the free access to public information and thus I would rate it as fairly good.

A structured interview in order to explore respondents in an orderly and comprehensive manner while obtaining first-hand information as well as keeping the interviewees focused on the subject of interest; the interview, designed to contain open questions that stimulate the participants' openness to provide more comprehensive information about the subject under consideration, was designed to collect more data about a particular subject that is the object of the research, namely the degree of inclusiveness/comprehensiveness of actors in the civil / non-governmental sphere, but also to get an alternative perspective to the institutional responses. In this regard, I contacted 15 civil society representatives taking into account their expertise in the field of European affairs and the possibility of direct participation in the process of preparing and substantiating the agenda of the Council Presidency in the first half of 2019. Among these, only five expressed their willingness to participate in an interview that took place via electronic correspondence (via e-mail). The information received from the five experts was extremely useful because it revealed that there is a difference between the official version of the central authorities on the openness to dialogue and cooperation with civil society representatives and the latter's perception not only in the context of preparations for the Presidency of the EU Council, but also in general with regard to the involvement in the decision-making process at the level of the national system for coordinating European affairs. Thus, I consider that the interview method was extremely useful not only to gather more data on the degree of inclusion of nongovernmental actors in the management of European affairs at national level, but also to check whether the apparent inclusiveness of the national coordination, based on certain normative provisions, is real in practice.

Documentary analysis used as a complementary basis for research as well as a validating method in relation to the data collected through the interview and questionnaire methods. In this sense, I have used different types of documents that can be grouped in the following categories: legislative texts and official 
documents published by the institutions of the central public administration (reports, press releases, questions and interpellations of the Parliament of Romania). The legislative texts have been extremely useful in mapping out the development of the national system for the coordination of European affairs since its inception to the present, but also to understand the basis of dialogue and cooperation with the civil society representatives in the framework of the national system for coordination of European affairs. Moreover, this type of documents was the basis on which I built the first part of the applied research and without which I could not have obtained a comparative view of the way in which the national coordination system is organized and operates during an ordinary period of activity versus how it functions and how it is organized during the preparation of the EU Council Presidency. In other words, I would not have been able to identify the potential for change of this event and therefore I could not have analysed whether or not the EU Council Presidency is a critical juncture in the development of the national system for coordination of European affairs. On the other hand, the official documents published by the competent institutions in the central public administration, such as reports, press releases and questions and interpellations of the Parliament, have been a valuable source of information on various aspects, such as the degree of inclusion of civil society representatives in the decision-making process in the context of the preparations for the EU Council Presidency.

\section{THE INTER-INSTITUTIONAL RELATION OF THE GOVERNMENT WITH THE CIVIL-SOCIETY/ NON- GOVERNMENTAL ACTORS}

The first reference regarding the involvement of the civil society in the field of European affairs at national level, in the beginning had nothing to do with consultations or the active participation of civil society actors in the formulation of the national position on European integration issues; rather, the Romanian government, through the Department for European Integration (DEI), assumed 
the responsibility to "ensure an informational flow through period newsletters regarding the evolution of the national and European integration process aimed at disseminating the European idea among the civil society" (Article 2, Government Decision no. 141 of March $9^{\text {th }}$ 1995). Therefore, the government, according to the provisions of the Decision no. 141/1995, had the obligation to inform the civil society of the developments related to the European integration of Romania in the monitoring stage. Later, during the negotiation for accession stage, the provisions regarding the involvement of civil society representatives in European affairs became more straightforward and paved the way for a real participation of non-governmental actors in the preparatory process for accession to the EU. In this sense, the Government Decision no. 14 of January $4^{\text {th }} 2001$ contains a provision referring to the possibility for social partners and civil society and/or interest groups' representatives to take part in the working sessions of the inter-ministerial committee for European integration, an operational body that coordinated, analysed and debated the documents elaborated by the institutions with competences regarding the accession to the EU (Article 11). In addition, the decision-makers' initiative to periodically inform the civil society of the evolution of the national and European integration process, as well as promoting the values and core elements of the EU, gained continuity at least formally through legal provisions contained by the Government Decisions regulating the institutional architecture for coordination of European affairs (Government Decision no. 1075/2001 on the organisation and functioning of the MEI) during the pre-accession stage.

Lastly, during the post-accession stage, the three major legal acts that established and modified the national system for coordination of European affairs (Government Decision no. 115/2008, Government Decision no. 379/2013 and Government Decision 34/2017) contained provisions which created the possibility for a wide range of non-governmental actors to participate in the formulation of the national position at the lower levels of the coordination and decision-making system for European affairs, namely at the level of the Committee for coordination and the working groups. Actually, in the beginning, the access of non-governmental actors was restricted to the level of working groups [Article 8(9), Government Decision no. 115/2008], but this aspect 
changed in 2013 when the entry into force of the Government Decision no. 379 marked the second major institutional overhaul in the coordination of European affairs in Romania, as well as an extension of the legal participatory basis towards the level of the Committee for coordination [Article 5(7)]. The Government Decision no. 34/2017, representing the current regulatory framework for the functioning and organization of the national system for coordination kept the provisions regarding the possibility for civil society actors to take part in the reunions of the Committee and working groups intact. What is more, the simple analysis of the content of the regulatory acts which formed the basis for and shaped the national institutional architecture for coordination of European affairs from 1995 until the presents indicates that there are only a few provisions containing references to any form of collaboration between the government and the civil society regarding the integration process or other EUrelated aspects in the pre-accession phase. Actually, the first reference of this kind was made in 1995 (Government Decision no. 141/1995), another one can be encountered in the text of the Government Decision no. 1075/2001 on the organization and functioning of the MEI, after which there is a long pause until 2008 when finally, during the post-accession phase, the focus on the issue of inclusiveness related to the participation of non-governmental actors in the elaboration of the national position becomes more nuanced and continuous.

A worth mentioning aspect is that when comparing the pre-accession and postaccession periods, even the references as to who can participate in the decisionmaking on European affairs are more complex or specific in the latter case; all three major legal acts that established and amended the functioning of the national coordination system (Government Decision no. 115/2008; Government Decision no. 379/2013 and Government Decision no. 34/2017) after 2007 specify that the following categories take part in the reunions of the Committee for coordination and the working groups: specialists from the Romanian Academy, the European Institute of Romania, the scientific research institutes, the higher education system, the non-governmental organizations as well as independent experts [ Article 8(9), Government Decision no. 115/2008; Article 5(7) and Article 6(6), Government Decision no. 379/2013; Article 6(7) and Article 7(6), Government Decision no. 34/2017]. Therefore, in the post-accession period, the 
national coordination system appears to be characterised by a fair degree of inclusiveness with concern to non-governmental actors at least in theory. Since there is no documented research on the inclusiveness of/ or the relation between the institutions in charge of coordinating European affairs/with responsibilities in managing EU-related issues and the civil society actors since Romania embarked on the path of European integration more than two decades ago, I can only assume that the obvious differences reflected by the legal acts with regard to this aspect in the pre and post-accession stages are inherent to the developments in the integration process of Romania. In other words, in the preaccession phase, for the most part, the focus was on building a coherent institutional arrangement for coordinating the negotiation talks and the overall process of European integration of Romania which often meant the centralization of the entire process in the hands of the MFA or another body directly subordinated to the Prime-Minister, as well as the decision-making was made at a single highest level. The nature of the integration process at that time left little room for the involvement of other institutional actors of the central public administration such as the Parliament and almost no concern regarding the relationship with non-governmental actors on European affairs.

Nevertheless, after the accession and achievement of the full membership, the status of Romania changed and with it its responsibilities and obligations grew more complex in the framework of the EU and every change to the institutional system operated so far has been made in order to reflect the new status and the legal institutional amendments of the EU as well as to improve Romania's participation in the EU decision-making process. In this context, the relationship between the Parliament and the Government and between the Presidency and the Government in coordinating European affairs has intensified. In the same note, it appears that the attention to the issue of involving the civil society's representatives/non-governmental actors in the lower decision-making levels of the national coordination system for European affairs has formally intensified as well. I keep suggesting that the issue of improving inclusiveness with regard to the national coordination of European affairs is only apparent/formal within the provisions of the legal acts regulating the functioning of the national coordination system because I believe that a distinction between a seemingly fair 
degree of inclusiveness that should characterise the coordination system according to the current normative framework and the actual situation as revealed during the analysis of interviews with several civil society representatives (NGO activists, European affairs experts and members of the academia) conducted for my research is necessary. The answers I received have revealed that the attitude of the MFA towards the engagement of the civil society in consultations on European affairs is rather reluctant and often the perception of civil society actors on the openness of the MFA is that although the process seems very transparent and accessible, it is reserved only for certain experts. One of the interviewees has actually admitted that on sectorial subjects, even when those were in connection or pertaining to the field of European affairs, the discussions were initiated by the line ministries which, in turn discussed the respective aspects with representatives of the MFA, and finally with representatives from the civil society.

Another expert who answered my questions felt that there is not sufficient promotion regarding the openness of the MFA for the engagement of other actors, which makes it more difficult for those interested professionals to participate in meetings at the level of the national Committee for coordination or at the level of the working groups. Overall, among the civil society representatives I have interviewed there is the awareness of the need for cooperation between the MFA and the civil society actors with the aim to identify the best answers to the current challenges arising in the process of interinstitutional coordination regarding the adoption of the national position in the field of European affairs as this implies pooling a higher level of expertise from both the central administration and the civil society. On the other hand, although there are legal provisions which provide the opportunity for nongovernmental/civil society actors to participate in the formulation of the national position at lower levels of decision-making - as I have previously shown -, in reality this rarely happens because the manager of the national system for coordination of European affairs, namely the MFA, does not sufficiently promote a higher degree of inclusiveness of other actors either by directing specific actions in the field or reaching to the civil society's experts to provide expertise on European policies. The engagement of the civil society in discussing European 
affairs is either left at the discretion of the line ministries or the civil society itself which initiates debates on various EU-related subjects of interest. This finding is further substantiated by the interviews when talking about the involvement of civil society representatives in the preparation of the Romanian Presidency of the Council which I will address in the next chapter. Finally, I could add my own experience to support the claim that the openness of the MFA towards actors or even ordinary citizens uninvolved in the national system for coordination of European affairs is relative.

In my attempt at collecting data for the current research, I have reached out directly to several public servants working in the MFA, at the Cabinet of the Delegate Minister for European Affairs, with the aim at clarifying aspects related to the preparatory process of the Council Presidency, but the feedback was instant and ended with a refusal to share any information regarding the subject or European affairs in general. The reason I was given was related to the nature of their activity and confidentiality. This came as a surprise as the subject is closely connected to the coordination of European affairs which in turn are part of the internal public policy cycle and are not submitted to secrecy protocols as it might happen in the case of foreign policy. What is more, my entire inquiry process into the theme of coordinating European affairs at national levels and the preparation of the Romanian Council Presidency was based on public information from official sources which needed further clarification in order for me to be able to understand how the system for coordination functions, which institutional actors are involved, what is the relation between them and whether the system suffered transformations during the preparatory process for the Council Presidency; thus, I consider that the refusal on the part of public servants in the MFA to discuss anything related to this subject or European affairs in general validates the perception of the civil society representatives interviewed regarding the relative degree of openness of the MFA towards communication and cooperation with actors from outside the central public administration. In conclusion, I would say that while the normative framework contains provisions offering the possibility for non-governmental/civil society actors to become involved in the decision-making on European affairs at the lower levels of the national system for coordination, in reality their engagement by the MFA 
is under-promoted and reserved for certain experts. Additionally, the information collected through the interviews suggested that the line ministries are more open for collaboration and dialogue with civil society representatives than the MFA which is in charge of the national system for coordination. An explanation for this could be the fact that the coordination of European affairs, although managed by the Cabinet of the Delegate Minister, is according to the law the responsibility of the MFA whose nature of activity makes it less accessible for other actors.

The aim of this chapter has been, on one hand, to map out the development of the national system for coordination of European affairs since its inception in 1995 until present in order to establish the degree of centralization/decentralization characterising it (by looking at the position of the institutions concerned), and, on the other hand, to establish the degree of selectivity/comprehensiveness of the system by looking at the actors participating in the formulation of the national position of Romania. In the first case, my analysis has concluded that the national system for coordination of European affairs is characterised by a high level of centralization with the MFA acting as a centralizer due to its role as manager of the coordination process. In the second case, the analysis focused on the role of the Parliament, the Presidency and the non-governmental/civil society actors in the decisionmaking process at the level of the national system for coordination of European affairs; the findings indicate that overall the process of coordination is characterised by a fair degree of comprehensiveness which is rooted in the normative framework regulating the functioning of the system, as well as the relation between the executive and the legislative. However, the engagement of the legislative differs from the Presidency or the civil society actors'; while the relation between the Parliament and the Government in the field of European affairs has a solid legal basis which allows the first to control the actions of the latter during the decision-making process, the inter-institutional relation of the Presidency with the Government is poorly regulated which has often sparked tensions and conflicts regarding the positioning of the first as the main public communicator on European issues - a role that legally pertains to the government -, but has also allowed the Presidency to assume a hierarchical role 
instead of working with the Government as equal partners in the coordination process (both institutions representing the executive power). The cooperation between the government and the actors from the civil society in the field of European affairs is backed by provisions that provide the possibility for the latter to participate in the formulation of the national position at the lower levels of the national system for coordination which constitute a firm basis for consolidating the degree of comprehensiveness. Nevertheless, my research has shown that the openness of the MFA, as manager of the coordination process, towards dialogue and cooperation with the civil society representatives is rather low in reality, while the line ministries are more willing to engage them in discussing sectorial issues. In this context, I would say that overall the national system for coordination of European affairs displays a fair degree of comprehensiveness/inclusiveness of other institutional and non-governmental actors, but this degree has its nuances given by the government's relation to each of the three actors.

Building on the analysis conducted in this chapter, I will further investigate whether the national system for coordination of European affairs has suffered any changes in the context of the preparations for the Romanian Presidency of the Council; the aim of the following section is to establish a causal link between the changes and the Presidency of the Council in an attempt at proving the research hypothesis that the latter is a significant event that can affect the development of the national coordination system. In order to fulfil this objective, I will analyse the transformations related to the inter-institutional relation of the Government with the civil society/non-governmental actors which is indicative of the degree of comprehensiveness/inclusiveness of the system. Also, the analysis will be based on relevant data obtained through the application of several questionnaires addressed to the public institutions with competences and responsibilities in the field of European affairs within the Government's composition, the Parliament, the Presidency, or data obtained from the interviews with civil society actors, as well as from documents of the two Chambers of the Parliament (questions and interpellations) or the MFA (the reports of the working groups of the Public Consultation Forum "EU-RO 2019") available on the websites run by these institutions. 


\section{THE INSTITUTIONAL RELATION OF THE GOVERNMENT WITH THE CIVIL SOCIETY/NON-GOVERNMENTAL ACTORS IN THE CONTEXT OF THE PREPARATORY PROCESS FOR THE COUNCIL PRESIDENCY}

The process of establishing the priorities and programme of the Presidency of the Council is a very complex task for any member state which must take into account the current agenda of the EU, as well as the main legislative dossiers under negotiation. In this sense, Romania will be in the position to propose for debate subjects of major interest for the country and work towards their advancement on the agenda. This means that the Romanian Government must take every necessary step in order to formulate clear objectives for the six-month mandate at the helm of the Council and pool all the expertise available at the level of the public administration, as well as from the civil society/nongovernmental actors. The two Memorandums released by the Romanian Government in 2016, respectively in 2017 acknowledged the need to involve all relevant actors both from the public and private sphere in the process of shaping the priorities and programme for Romania's Council Presidency. This activity, complementary to the one taking place at governmental level, will be carried out following a comprehensive and wide process of public consultations, analysis and debates. The start of the public consultations was given on October $24^{\text {th }} 2016$, in Bucharest, during a public event ${ }^{1}$ hosted by the then Prime-Minister Dacian Ciolos, who presented a calendar of public debates to be organized in the period November 2016 - June 2017. These debates have been organized with the support of the European Institute of Romania, the Romanian Diplomatic Institute, as well as the Info-Europa Centre and their thematic approach followed the logic of the EU Council's configurations. The line ministries endorsed the subjects proposed during the debates at the meetings of the inter-ministerial

${ }^{1}$ For more information please access https://haga.mae.ro/local-news/1196; last accessed in June 2018. 
Council and forwarded them to other relevant institutions with competences in the field of European affairs for contributions.

However, only half of the envisaged public consultation events were organised in the last two months of first half of 2017 with regard to subjects such as the energy security of Europe, the impact of migration on the labour market at European level, the multi-annual Financial Framework post-2020 (organized in partnership with the Ministry of Public Finances), the free circulation on the EU labour market (organized in partnership with the Ministry of Labour and Social Justice) or the challenges and priorities of the European project and the issue of foreign affairs within the EU context (institutional answer from the MFA to the parliamentary question of Adrian-Claudiu Prisnel, MP) ${ }^{1}$. These events, organized during the Cabinet of Mihai Tudose, did not have the anticipated impact regarding the inclusion of an important part of the civil society actors who had the feeling that the public authorities did not take sufficient action to engage them in the organization of the EU Council Presidency which also contributed to the perception that the overall preparatory process was delayed. This situation prompted several non-governmental organizations with expertise in the field of European affairs to address an open letter ${ }^{2}$ in June 2017 to the newly appointed Delegate Minister for European affairs in which they signalled the lack of any coordination measures or mechanisms with the civil society actors in the contents of the two Memorandums released by the Government, as well as the low level of communication and inclusiveness of civil society experts, members of the academia or journalists by the former cabinets in the preparatory process for the EU Council Presidency.

Moreover, the letter highlighted the ambiguity related to the organization of the public consultation events in terms of the subjects approached, objectives, time

1 Parliamentary question no. 1532A/20-09-2017, available at URL: http:/ / www.cdep.ro/pls/parlam/interpelari.detalii?idi=49288\&idl=1; last accessed in June 2018.

2 The full content of the letter can be read at URL: https://www.stiri.ong/institutii-silegislatie/romania/scrisoare-deschisa-pregatiri-presedintia-romana-a-consiliului-ue; last accessed in June 2018. 
and place. The same impression, that the debates were not sufficiently promoted in order to stimulate the early participation of civil society representatives, was shared with me by one of the experts I interviewed. Finally, the letter reminded the Delegate Minister that the civil society engagement is valuable not only from the perspective of sharing ideas and forwarding proposals regarding the preparations of the Council Presidency, but also from the perspective of the role these actors can play in the implementation of the Presidency's calendar, including raising the public awareness with respect to the significance of this task or the promotion at European level of the country's priorities and objectives prior and during the exercise of the mandate by Romania.

Following this address, the Delegate Minister ensured the civil society actors of the MFA and the Government's willingness to conduct a very transparent and inclusive preparatory process for all relevant actors and their contributions in the preparatory process for the Council Presidency. The Delegate Minister also informed the public of the Government's intention to accelerate the preparatory process both in terms of coordination of the structures with responsibilities in the field of European integration and establishment of the permanent dialogue and cooperation with the non-governmental sector ${ }^{1}$. In this sense, the MFA launched in the second half of 2017 a campaign, titled "European Dialogues", comprising a series of 11 public debates in cooperation with several line ministries (the Ministry of Communications and Information Society; the Ministry of Transports), public universities (Bucharest University of Economic Studies; Babeș-Bolyai University of Cluj-Napoca; University of Agronomic Sciences and Veterinary Medicine of Bucharest, etc.) and public institutions (the European Institute of Romania; the Romanian Diplomatic Institute) that were attended by think-thank representatives, academics and experts on sectorial policies/EUrelated issues. The public debate campaign continued in the first month of 2018 with other 9 relevant events being organized under the auspices of the MFA and in partnership with public universities from other cities in Romania (Iași, Pitești,

1 The full response of the Delegate Minister to the civil society's open letter can be read at URL: https://www.mae.ro/node/42440; last accessed in June 2018. 
Sibiu) and institutions. The organization of these events all over the country indicates the government's, respectively the MFA's, attempt to raise awareness of the preparations related to the Romanian EU Council Presidency in 2019 and engage a greater number of public and private actors in shaping the political agenda of the future Presidency. The themes of the debates organized so far ranged from discussing the reform of the Common Agricultural Policy and Cohesion Policy, competitiveness, the future of the EU and digitalization to Romania's accession to the Euro area and the future 7 year Multi-annual Financial Framework. ${ }^{1}$ Further information provided by the MFA revealed that the Government was intensifying its efforts at putting together the line ministries' proposals for a diversified and comprehensive calendar regarding the events and informal reunions during the exercise of the Presidency to include as many actions as possible at local level and civil society representatives as early as the summer of 2017 (institutional answer from the MFA to the parliamentary question of Adrian-Claudiu Prisnel, MP).

However, the most prominent action taken by the MFA, through the Delegate Minister, to highlight the transparency and inclusiveness of the process regarding the establishment of the Romanian EU Council Presidency's agenda was the creation of the public consultation, debate and communication Forum in view of preparing and exercising the Presidency - EU-RO 2019. The Forum was created through the MFA and the Delegate Minister's Order no 1688/September $25^{\text {th }} 2017$ with a mission to establish the institutional framework for debate with civil society representatives regarding the subjects of interest for Romania during the exercise of the Presidency in 2019. The official launching of the Forum took place on January $25^{\text {th }}, 2018$, at the headquarters of the National University for Political Studies and Public Administration, in the presence of numerous representatives of public authorities, local and central administration, employers' representatives, trade unions, academics, members of civil society, journalists and representatives of Romanian delegations within the consultative structures

1 The integral list of public debates and details about the organization, theme and attendance of each event can be consulted at URL: http:/ / www.romania2019.eu/calendar-de-dezbateri-publice/; last accessed in June 2018. 
of the European Union, the European Economic and Social Committee, respectively the European Committee of the Regions ${ }^{1}$. This consultative structure, under the coordination of the Delegate Minister for European affairs, organized two working sessions between February $1^{\text {st }}$ - March $1^{\text {st }}$, with the participation of 500 representatives from the civil society in 17 groups constituted along the thematic lines of the EU Council's configurations. Each group was headed by a coordinator/facilitator, tasked with centralizing the proposals from the participants and drawing up the final report of the meetings (institutional answer, Ministry of Foreign Affairs). Each group was also assisted by representatives from the MFA who provided feedback to certain proposals on request and took care of the logistical aspects regarding the manner to conduct the meetings. Upon completion of the first stage of consultations and debates in an institutional format, the MFA's reaction, through the Delegate Minister, was very positive regarding the amount of proposals received from the civil society representatives. In this sense, the MFA publicly announced that the reports of the Forum would be sent to the line ministries to be analysed and, if found relevant, integrated in the reflection process dedicated to shaping the political agenda for the EU Council Presidency in 2019. Finally, the Delegate Minister informed the public that the consultations would be continued at the same time inviting every person interested to contribute to the substantiation of Romania's positions during the exercise of the Presidency, as well as in the wide context of the EU decision-making process through an online questionnaire available on the website dedicated to the preparation of the Council Presidency ${ }^{2}$.

However, upon analysing the opinions and suggestions in several reports ${ }^{3}$ prepared by the working group (WG) coordinators, the overall quality of the

${ }^{1}$ For more information please access https://www.mae.ro/node/44806; last accessed in June 2018.

2 The integral press release of the MFA can be read at URL: http:/ / www.romania2019.eu/2018/03/02/victor-negrescu-forumul-eu-ro-2019-agenerat-multe-idei-constructive/; last accessed in June 2018.

3 The reports of the following Working Groups (Justice; Economic and Financial Aspects; Regional Development; Agriculture and Fisheries; Foreign Affairs and Defence; 
consultation process during the meetings of the Forum was not the best. Also, the interviews I have conducted support the critical points of view formulated with regard to the organization of the debates as four of the five experts approached have been involved in these consultations either as ordinary participants or as group coordinators. The five reports in question and the interviews point to several factors that have contributed to the weaker quality of discussions and the final contributions of each WG. First of all, it is generally agreed among participants that the time for reflection allocated to each party ( 2 face-to-face meetings) by the coordinator of the Forum was insufficient for the elaboration of more qualitative and specific proposals in the sectorial fields relevant for the preparation and implementation of Romania's political agenda during the exercise of the EU Council Presidency. Secondly, the participants have noted that the overall organization of the Forum was done in a hasty manner correlated to the amount of time provided to develop proposals and run a selection of the most relevant in order to be forwarded to the MFA for analysis, but also to the extremely rapid acceptance of the expert's candidacies to actively participate in the Forum. Third, while in the first session of debate, the participation and active involvement of the WGs' members were high, their expectations for the second round of discussions dropped together with their interest to participate and give feedback to the ideas that were taking shape; some of those present have renounced to express their opinions and/proposals and even leave the WGs. Two of the working group coordinators share the opinion that this might have come as a result of the complexity of the themes under discussions, which required more time for thinking between the two sessions, as well as the optimal formula sought by the organizers regarding the technicality of the proposals and the European dimension given to the entire process of debate and consultation which limited the direct interest of the participants. As the coordinator of the Foreign Affairs and Defence WG was noting in his report, the majority of participants in the meetings of his party were

Employment and Social Policy) can be consulted at URL: http:/ / www.romania2019.eu/agenda-dezbaterilor/; last accessed in June 2018. 
rarely focused on the actual themes of the group and most of the time their proposals were suited to the thematic fields of other WGs. This points to a fourth determining factor for the quality of the consultations and their final output, namely the different levels of knowledge and expertise of the participants regarding the European objectives and latest developments in the EU sectorial policy fields. In this sense, the worst lack of expertise was, according to the report, encountered by the Foreign Affairs and Defence WG whose coordinator agreed with the MFA's representatives that an off the record meeting be held with relevant non-governmental organizations (ASPEN Institute, New Strategy Centre, Romanian Centre for European Policies, Centre for Conflict Prevention and Early Warning) separately to the activities in the Forum in order to offer a substantiated contribution to the priorities of the future Romanian Presidency of the Council in this field. Lastly, the reports and interviews revealed that the final contributions of the WGs were obtained through the centralization of proposals via e-mail, web-based document editors - Google Docs - or telephone, which indicates an alternative solution to communicate between the members of the working parties considering the limited time for face-to-face consultations; while the use of electronic communication was indeed a solution in this context, it is still true that this did not ensure the equal engagement of participants and, thus, it did not help in the formulation of substantial proposals.

Despite the major organization flaws of the consultation Forum, the initiative of the MFA was appreciated by all actors involved as a real institutional attempt of the national coordinator for European affairs at creating a framework for dialogue with the civil society's representatives in the context regarding the preparations for Romania taking over the EU Council Presidency. Taking into account the rather low degree of inclusiveness of other institutional and nongovernmental actors that generally characterises the national system for coordination of European affairs (even more the MFA, as the institution in charge of running the system, than the line ministries as I have already mentioned in the previous chapter), the openness of the MFA is considered a rare opportunity by the civil society actors to participate in the decision-making process on European affairs as they have long been wanting and asking for (see the open letter addressed to the Delegate Minister). The WGs' reports and the 
interviews mention the express desire of the civil society experts to continue working together to identify the challenges and opportunities that might arise during the exercise of the EU Council Presidency both at central and local level. Actually, one expert felt that the activities of the Forum were mostly accessible for actors from the capital considering that the consultations have been exclusively held in Bucharest, which indicates the necessity to broaden the process in order to give civil society actors from all over the country and at all levels the possibility to participate in the debates organized by the MFA. However, it is unclear how the dialogue with the civil society actors will continue beyond the format of the EU-RO 2019 Forum.

The experts I have interviewed relied to me that they were unaware of the MFA's plans in this direction although they expressed their availability to maintain the cooperation with the central administration in the context of the preparation and exercise of the Presidency. Instead, the MFA would provide the civil society representatives with the opportunity to forward proposals regarding the organization of certain events under the auspices of the EU Council Presidency that would be selected based on a list of criteria established by the MFA. It appears that the engagement actions would further originate from the civil society rather than the Government which would not be surprising as the experts interviewed noted that generally the desire and openness to engage in dialogue with the institutions in the central administration comes from the nongovernmental side. Additionally, it is important to highlight that the questionnaire available on the website dedicated to the organization of the Presidency (referred to by the Delegate Minister in the press release immediately after the end of consultations in the Forum) was discarded by the experts interviewed as an efficient method to enhance the involvement of citizens in shaping the national position of Romania as there is no feedback mechanism involved. Therefore, in the absence of other initiatives from the organizers, the civil society actors contacted several line ministries in order to ensure their cooperation and support to organize public debates on EU-related issues of relevance for the future Romanian Presidency of the EU Council. In this sense, two experts pointed to the initiative of the Digital Citizens think-thank, which obtained the support of the Ministry of Communications and Information 
Society, to organize a wide consultation and promotion campaign (Leaders in the Digital rEvolution) regarding the priorities in the digital sector, based on the Forum's contributions, at both national and European level. The aim of the campaign would also be to look beyond the context of the EU Council Presidency to the contributions that could be brought by civil society actors in the process of shaping the post-2020 Digital Agenda. According to the personal and professional experience of one expert from the civil society, the institutional relation with the line ministries should be cultivated more with regard to the capitalization of expertise necessary for the establishment and later implementation of Romania's agenda for the EU Council Presidency; in her opinion, the contributions of the civil society actors would be more relevant and realistic if this relation were managed by each line ministry and less by the MFA (which is already in charge of coordinating the whole process of decision-making on European affairs) with regard to sectorial issues. In this context, the MFA should only fulfil its responsibility of institutional coordination regarding the preparation and exercise of the EU Council Presidency, thus ensuring the general guidelines of the process and less a facilitating role in the direct institutional relation to the civil society on sectorial matters.

From what was revealed by the reports of several WGs within the EU-RO 2019 consultation Forum and the interviews held with several civil society representatives with expertise in the field of European affairs, as well as from the MFA's answers to parliamentary questions and interpellations, the degree of inclusiveness/comprehensiveness of the national coordination system for European affairs has been enhanced in the context related to the organization of the EU Council Presidency. In this sense, it is important to highlight the gradual engagement of civil society actors in the process of establishing the political agenda for the Presidency as the latter progressed across the coordination of different successive cabinets. In this sense, the start of the consultation process was given almost at the end of 2016 by the government of Dacian Cioloș through the organization of a kick-off conference which introduced the calendar of public debates for the next six months. However, less than half of the public events scheduled actually took place and their visibility was rather low, as the experts interviewed confirmed; this has not only generated a weak involvement of the 
civil society actors in the first half of 2017, but also the reaction of several prominent non-governmental organizations to express their dissatisfaction regarding the lack of transparency, inclusiveness and communication of the Government about the slow evolution of the preparatory process. Consequently, the newly appointed Delegate Minister for European Affairs in the Mihai Tudose Cabinet reassured the civil society representatives of the MFA's and the Government's overall desire and interest to include as many public and private actors as possible to contribute to the shaping of Romania's EU Council Presidency political agenda. In this sense, the MFA intensified the public consultation and debate campaign both at central and national level, in partnership with several line ministries with competence in the field of European affairs, as well as public institutions from the academic and research sphere from several important cities in Romania, in an attempt at gradually building a steady and strong connection to the civil society actors. In addition, the MFA's greatest achievement, from the perspective of the Delegate Minister, was the creation of the EU-RO 2019 Forum which was intended as a formal framework for dialogue with civil society representatives on the themes related to the EU Council Presidency. The great number of participants (500 people) and the output of the working sessions of the Forum was very appreciated by the organizers who committed themselves to integrate the relevant contributions into the reflection process carried out at the level of the line ministries to define the topics of interest and the promotion objectives for the Romanian EU Council Presidency in the first semester of 2019.

However, my research has revealed that the perspective of the experts directly involved in the working sessions of the consultation Forum differs to a great degree from the official one with regard to the overall success and quality of discussions and contributions resulting at the end of the process. The main factors highlighted by the interviewees and the reports of several WGs, as negatively affecting the whole process of consultation, were related to the very organization of the Forum. In this sense, the limited time for consultations and drafting proposals (the consultations were condensed in only two working sessions), the heterogeneity of the participants with different levels of knowledge and expertise on the sectorial themes of the WGs, the lower participation in the 
second and final consultation session and last, but not least, the hasty manner in which the approval of experts' applications was made correlated to the little amount of time for reflection between meetings and the communication methods used to compensate for the limited face-to-face time, diminished the possibility to draft more substantiated and specific proposals. Despite the participants' feeling that the consultation Forum could have been better organized in order to bring out the full potential of the experts and foster better contributions, the general opinion was that the initiative of the MFA to provide a formal framework for consultations with the civil society, and at the same time continuity to this process, was a rare occasion in which the MFA was this open to the engagement of civil society actors in activities related to the coordination of European affairs. As such, the civil society representatives believe that this opportunity should be taken in order to step up their involvement in the preparation and exercise of the EU Council Presidency even though it would mean that the extra effort would come from the non-governmental side as it usually happens in the relation with the public institutions with competences in the field of European affairs. Unfortunately, the expectations of the civil society representatives with regard to the continuation of the debate in the framework of the Forum are still far from being met. While it is true that after the first stage of consultation and debate within the Forum there have been several other public events of sectorial issues organized at central and national level, the experts interviewed admitted to not having further information on the plans of the Government, respectively the MFA, to continue working with the civil society through this arrangement (the Forum) or within other formats. Therefore, some of them relied to me that they would rather seek to establish a functional cooperation with the line ministries on sectorial issues of interest in the context of the Romanian EU Council Presidency as their contributions would be better integrated. In conclusion, considering all the aspects revealed through my research, the degree of comprehensiveness/inclusiveness of the national system for coordination of European affairs in relation to the civil society actors has definitely improved in the context regarding the preparations of the Presidency compared to an ordinary period in the functioning of the coordination system 
(see more in the previous section) regardless of the general quality and depth of cooperation and dialogue.

\section{CONCLUSIONS}

The hereby paper is aimed at establishing whether the Council Presidency can be a critical juncture in the development of the national system for coordination of European affairs with respect to its nature in terms of the degree of inclusiveness/comprehensiveness of other non-governmental actors in the process of formulating the national position on EU-related issues. In this sense, my analysis has revealed that there are several normative provisions related to the possibility of civil society representatives to participate in the process of substantiating the national position of Romania at the lower levels of the coordination system. In reality, however, it turned out that the government's openness to dialogue with the civil society actors is low, especially in the case of the MFA, and the civil society representatives are generally the ones who initiate consultation with the central administration institutions with responsibilities in the coordination of European affairs. In the context of preparing the EU Council Presidency, I have noticed a gradual openness of the MFA towards dialogue and cooperation with civil society representatives in order to define Romania's priorities and political agenda for this mandate, which increased in the summer of 2017, when the European affairs portfolio at the MFA was taken over by the Delegate Minister Victor Negrescu. The gradual openness towards the involvement of the civil society actors I have referred to so far has consisted in organizing public debates on topics of interest for the Romanian Presidency in 2019 and the creation of the EU-RO 2019 Public Consultation and Debate Forum. The Forum is the most relevant initiative of the MFA regarding the establishment of a formal framework for dialogue with the civil society, and its organization was considered a success by the decision-makers. However, my research has indicated that the Forum was in fact relatively successful due to the poor organization of the meetings, which affected the quality of the experts' final contributions and did not have the continuity expected by the civil society 
representatives. In addition, the communication with the MFA outside the consultation and debate Forum has proved unproductive given that the civil society experts were unaware of any plans to further involve them in the preparation and subsequent exercise of the Presidency of the EU Council. In this regard, some of the experts I discussed with admitted that it was preferable to have a direct relationship with the line ministries in sectorial issues rather than the MFA, which should only retain the role of coordinator of the preparatory process at the national level while giving up the mediating role in relation to the line ministries. Despite the shortcomings expressed regarding the effectiveness of the consultation Forum and the public debate campaign organized by the MFA in partnership with public institutions in Romania, the civil society actors have generally appreciated the exceptional openness of the authorities in the context of the preparations for the Presidency of the EU Council and expressed their hope to continue to improve the dialogue between the two parties. However, with regard to the degree of inclusion of civil society actors in the process of establishing their national position in European affairs, the Presidency of the EU Council cannot be considered a critical juncture since there is much uncertainty regarding the way the dialogue with the public authorities will continue even in the near future. From what I understood from the civil society representatives I interviewed, it is highly likely that the openness shown by the MFA is only a one-time occurrence.

\section{REFERENCES}

- Adler-Nissen, Rebecca, Julie Hassing Nielsen, and Catharina Sørensen. 2012. "The Danish EU Presidency: A Mid-Term Report." Swedish Institute for European Policy Studies.

- Alexandrova, Petya, and Arco Timmermans. 2013. "National Interest versus the common good: The Presidency in European Council agenda setting." European Journal of Political Research 52: 316-338.

- Bergmüller, Florian. 2010. "Spain's Europeanist Presidency: Solid Starting Block for the European Council President and High Representative?." SWP Working Paper 2010/06. Berlin: Stiftung Wissenschaft Politik. 
- Capoccia, Giovanni, and Daniel R. Kelemen. 2007. “The Study of Critical Junctures. Theory, Narrative, and Counterfactuals in Historical Institutionalism." World Politics, no. 51: 341-369.

- Chamber of Deputies, Interpellation no. 1342A/06-09-2017, “The status of preparations of the Romanian state in view of ensuring the Presidency of the European Union", September 2017. accessed on June, 242018. http:/ / www.cdep.ro/pls/parlam/interpelari.detalii?idi=48989\&idl=1.

- Chamber of Deputies, Parliamentary question no. 1532A/20-09-2017, "Preparation of Romania for the Presidency of the European Council", September 2017. http:/ / www.cdep.ro/pls/parlam/interpelari.detalii?idi=49288\&idl=1.

- Dinan, Desmond. 2013. "The Post-Lisbon European Council Presidency: An Interim Assessment." West European Politics 36, no. 6: 1256-1273.

- Government of Romania. 1995. Government Decision no. 141 on the organization and functioning of the Department for European Integration of March 9, 1995.

- Government of Romania. 2001. Government Decision No. 1075 on the organization and functioning of the Ministry of European Integration of 25 October 2001.

- Government of Romania. 2001. Government Decision no. 14 on the creation of the Ministry of European Integration of 4 January 2001.

- Government of Romania. 2008. Decision no. 115 of 30 January 2008 on the establishment of the national system for coordination of European affairs in view of Romania's participation in the decision-making process of the European Union institutions.

- Government of Romania. 2013. Government Decision no. 379/2013 on the organization and functioning of the European system for the coordination of European affairs.

- Government of Romania. 2017. Government Decision no. 34/2017 on the organization and functioning of the national system for the coordination of European affairs.

- Jensen, Mads Dagnis, and Peter Nedergaard. 2014. "Varieties of trio Presidencies in the Council of Ministers." Journal of Common Mark Studies 52: 1035-1052.

- Kaczynski, Piotr Maciej. 2011. "Polish Council Presidency 2011: Ambitions and Limitations." Swedish Institute for European Policy Studies. Stockholm. 
- Kaniok, Petr, and Leona Gergelová Šteigrová. 2014. "Presidency and State Administration in the Czech Republic: Planting a Seed or a Shattered Chance?." Journal of Contemporary European Research 10, no. 3: 337-354.

- Karlas, Jan. 2009. "The Executive Coordination of the Czech EU Presidency." Paper presented at the ISA Conference, New York (USA): Institute of International Relations.

- Karolewski, Irenusz Pawel, Thomas Mehlhausen, and Monika Sus. 2015. "The Polish EU Council Presidency in 2011: Master or Servant?." Journal of European Integration 37, no. 6: 667-684.

- Lajh, Damjan. 2010. "The Executive Coordonation of the Slovenian EU Presidency: An Honest Broker." In The Czech and Slovenian EU presidencies in a comparative perspective, edited by Peter Drulak and Zlatko Sabic. Dordrecht: Republic of Letters Publishing.

- Ministry of Foreign Affairs. 2016. “START for 2019. Romania's Presidency of the EU Council”, October 2016. https:/ / haga.mae.ro/local-news/1196.

- Ministry of Foreign Affairs. 2017. "Answer by Delegate Minister for European Affairs Victor Negrescu to the letter from civil society organizations on the future EU Council Presidency", July 2017. https://www.mae.ro/node/42440.

- Ministry of Foreign Affairs. 2018. "The debates of the "EU-RO 2019" Forum on the topics of interest of the Romanian Presidency to the Council of the European Union have started", January 2018. https://www.mae.ro/node/44806.

- Press Release. 2018. "Victor Negrescu: the EU-RO 2019 Forum generated many constructive ideas", 2018. http:/ / www.romania2019.eu/2018/03/02/victor-negrescu-forumul-eu-ro2019-a-generat-multe-idei-constructive/.

- Puetter, Uwe. 2014. "The Rotating Council Presidency and the New Intergorvernmentalism." The International Spectator 49, no. 4: 18-32.

- Raik, Ele. 2015. "The Trio Presidency of the Council of the European Union: Towards more continuity?." Baltic Journal of European Studies 5, no. 1: 19-35.

- Report of the Working Group "Agriculture and Fisheries." Forum EU-RO 2019, March 2018. http://www.romania2019.eu/wpcontent/uploads/2018/03/AGRICULTUR\% C4\%82-\%C8\%98I-PESCUIT.pdf.

- Report of the Working Group "Economic and Financial Aspects." Forum EURO 2019, March 2018. http://www.romania2019.eu/wpcontent/uploads/2018/03/ASPECTE-ECONOMICE-SI-FINANCIARE.pdf. 
- Report of the Working Group "Employment and Social Policy." Forum EURO 2019, March 2018: http://www.romania2019.eu/wpcontent/uploads/2018/03/OCUPAREA-FOR\%C8\%9AEI-DE-

MUNC\%C4\%82-\%C8\%98I-POLITIC\%C4\%82-SOCIAL\%C4\%82.pdf.

- Report of the Working Group "Foreign Affairs and Defence." Forum EU-RO 2019, April 2018. http://www.romania2019.eu/wpcontent/uploads/2018/04/GL-Afaceri-Externe.pdf.

- Report of the Working Group "Justice." Forum EU-RO 2019, March 2018. http:/ / www.romania2019.eu/wp-content/uploads/2018/03/JUSTITIE.pdf.

- Report of the Working Group "Regional Development." Forum EU-RO 2019, March 2018. http://www.romania2019.eu/wpcontent/uploads/2018/03/DEZVOLTARE-REGIONALA.pdf.

- Romanian Presidency of the Council of the European Union, "Calendar of Public Debates." accessed on June 24, 2018. http://www.romania2019.eu/calendar-de-dezbateri-publice/.

- Schout, Adriaan. 2017. "The Dutch EU Presidency: The Continuing Relevance of the Rotating Presidency in a Political Union." Journal of Common Market Studies 55 (Annual Review): 54-63.

- Smeets, Sandrino, and Jac Vennix. 2014. "How to make the most of your time in the Chair: EU presidencies and the management of Council debates." Journal of European Public Policy 21, no. 10: 1435-1451.

- SStiri ONG. 2017. “Open Letter Preparations for the Romanian Presidency of the EU Council", July 2017. https://www.stiri.ong/institutii-silegislatie/romania/scrisoare-deschisa-pregatiri-presedintia-romana-aconsiliului-ue.

- Udovič, Boštjan, and Marjan Svetličič. 2012. "Does the Trio matter? The case of the Slovenian EU Council Presidency." Romanian Journal of Political Science 12, no. 2: 4-28.

- Van Gruisen, Philippe, Pieterjan Vangerven, and Christophe Crombez 2017. "Voting Behavior in the Council of the European Union: The Effect of the Trio Presidency." Political Science Research and Methods: 1-16.

- Van Hecke, Steven, and Peter Bursens. 2011. Readjusting the Council Presidency. Belgian Leadership in the EU. Brussels: Academic \& Scientific Publishers.

- Vandecasteele, Bruno, and Fabienne Bossuyt. 2014. "Assessing EU Council presidencies: (Conditions for) success and influence." Comparative European Politics 12: 233-247. 
- Vandecasteele, Bruno, Fabienne Bossuyt, and Jan Orbie. 2013. "Unpacking the influence of the Council Presidency on European Union external policies: The Polish Council Presidency and the Eastern Partnership." In Agency and influence inside the EU institutions, European Integration online Papers (EIoP) 17, no. 1(Special Issue). Article 5: 1-28.

- Vanhoonacker, Sophie, and Adriaan Schout. 2002. "Reforming the EU Institutions - Challenges for the Council. The Rotating Presidency of the Council of the EU: Obstinate or Obsolete?." From the Convention to the ICG: Mapping Cross-National Views towards an EU-30: 1-19.

- Verhoeff, Emma, and Arne Niemann. 2011. "National preferences and the European Union Presidency: The case of German energy policy towards Russia." Journal of Common Market Studies 49, no. 6: 1271-1293.

- Vilpišauskas, Ramūnas, Bruno Vandecasteele, and Austė Vaznonytė. 2013. "The Lithuanian presidency of the Council of the European Union: advancing energy policy and Eastern partnership goals: conditions for exerting influence." Lithuanian Foreign Policy Reviews, no. 29: 11-37.

- Warntjen, Andreas. 2013. "The Elusive Goal of Continuity? Legislative Decision-Making and the Council Presidency before and after Lisbon." West European Politics 36, no. 6: 1239-1255. 